\title{
Assessment of germination time of finger millet for value addition in functional foods
}

\author{
Ashwani Kumar ${ }^{1,2, *}$, Amarjeet Kaur ${ }^{1}$, Kritika Gupta ${ }^{2,3}$, Yogesh Gat ${ }^{2}$ and \\ Vikas Kumar ${ }^{1,2}$ \\ ${ }^{1}$ Department of Food Science and Technology, Punjab Agricultural University, Ludhiana 141 004, India \\ ${ }^{2}$ Department of Food Technology and Nutrition, School of Agriculture, Lovely Professional University, Phagwara 144411 , India \\ ${ }^{3}$ Department of Nutrition and Hospitality Management, University of Mississippi, USA
}

In the present study, finger millet (Eleusine coracana) grains of variety VL Mandua-315 were soaked overnight and germinated $\left(25^{\circ} \pm 2^{\circ} \mathrm{C}\right)$ for varying time intervals ranging from 12 to $96 \mathrm{~h}$. Samples were drawn at every $12 \mathrm{~h}$ interval, dried at $50^{\circ} \pm 2^{\circ} \mathrm{C}$, deculmed, powdered and analysed for physicochemical composition, functional properties and mineral content. A significant increase $(P \leq 0.05)$ in sugars, crude fibre, ascorbic acid, antioxidant activity and water solubility index and decrease $(P \leq 0.05)$ in starch, protein and ash was found with increase in germination time. Fat, total phenols and tannins reached their minimal value after $48 \mathrm{~h}$ of germination followed by a linear increase. Water absorption index, oil absorption index, foam capacity and foam stability decreased with soaking, followed by a linear increase up to $60 \mathrm{~h}$ of germination. Amongst all minerals tested, calcium showed a significant increase with increase in germination time. A clustered heat map was used to depict the effect of germination time on the overall properties of finger millet.

Keywords: Clustered heat map, finger millet, functional foods, germination, physico-chemical properties, value addition.

MiLLETS have always remained one of the staple foods and serve as a vital crop to ensure food security in semiarid areas ${ }^{1}$. Earlier millets were considered as food of the low-income strata ${ }^{2}$. However, recent health claims like low glycaemic index, gluten-free, high amounts of dietary fibre and minerals have placed them in the category of functional foods ${ }^{3}$. In addition, the climate-friendly attributes of millets, viz. limited or no irrigation requirements, ability to grow on low fertile soil and resistance to insects and pests make them a natural solution to keep drylands productive ${ }^{4}$. Millets can fulfil this dual contrivance and in this connection, finger millet, one of the highly produced millets with high nutrient content, represents tremendous scope in countries like India, China and Pakistan where increase in dry areas has caused reduction in cultivable areas.

\footnotetext{
*For correspondence. (e-mail: ashwanichande1480@gmail.com)
}

India is one of the largest producers of finger millet with an area of 1138.2 thousand ha under its cultivation and production of 1821.9 thousand tonnes in 2015-16 (ref. 5). Finger millet is drought tolerant and grows best in saline soils, i.e. $\mathrm{pH}$ 5.0-8.2, which makes it a suitable crop for drylands ${ }^{4}$. It has excellent protein quality, wellbalanced amino acid profile and is considered one of the most nutritious grains ${ }^{6}$. Micronutrients (vitamins and minerals) like calcium, phosphorus, iron, thiamine, riboflavin and nicotinic acid are present in ample amounts ${ }^{7}$. Finger millet is rich in bioactive compounds that contribute to its antioxidant and antimicrobial properties ${ }^{3,8}$. However, the presence of anti-nutrients like trypsin inhibitors, phytic acid and some of phenolic compounds limits its food value as these compounds interact with essential nutrients like protein and chelate minerals and reduce their absorption ${ }^{9}$. Various processing techniques like popping, roasting, germination and fermentation are known to reduce anti-nutritional factors to a safe limit.

Germination is an important and economical method to reduce the anti-nutritional factors and increase the digestibility of finger millet ${ }^{10}$. Germinated grains can be dried to a safer moisture limit and stored for further processing. Chemical composition, functional properties and mineral content of the grains alter with germination. Hence, a study of these changes is important for development of finger millet-based food products with enhanced functional and nutritional quality. In the present study, the effect of soaking and germination on the quality attributes of finger millet was studied at every $12 \mathrm{~h}$ interval up to $96 \mathrm{~h}$.

\section{Materials and methods}

Finger millet (Eleusine corcana) grains of variety $\mathrm{VL}$ Manduaa-315 were procured from Vivekananda Parvatiya Krishi Anusandhanshala, Almora, Uttar Pradesh, India. The grains were cleaned by winnowing to separate the residual particles (husks, chaff and unmature seeds). The cleaned grains were collected and dried in a tray drier at $50 \pm 2{ }^{\circ} \mathrm{C}$ (Narang Scientific Works Limited) to a final moisture content of $8 \pm 0.5 \%$ and stored till further use. 
The moisture content of the samples was determined by oven-drying method at $130^{\circ} \mathrm{C}$ for $2 \mathrm{~h}$ (ref. 11).

\section{Malting loss}

This is a measure of the mass of grain lost in the germination process. It is calculated by subtracting the weight of dried germinated grains from non-germinated grains. The formula for calculating malting loss is

Total malting loss $(\%)=$

$$
\frac{\left(\begin{array}{c}
\text { Weight of the grains before malting }- \\
\text { Weight of grains after malting }
\end{array}\right)}{\text { Weight of the grains before malting }} \times 100 \text {. }
$$

\section{Nutritional, bioactive and functional properties}

Proximate analysis, viz. moisture, ash, fat and crude fibre was done according to the standard methods given by the Association of Official Analytical Chemists ${ }^{11}$. Sugars were determined following the methods given by the American Association for Cereal Chemists ${ }^{12}$. Crude protein content was estimated by micro Kjeldhal method ${ }^{12}$ and a factor of 6.25 was used to convert nitrogen into protein. Total phenols were measured by the colorimetric method of Singleton and Rossi ${ }^{13}$. Antioxidant activity was measured according to the method of BrandWilliams et al. ${ }^{14}$ using DPPH (2,2-diphenyl-1-picrylhydrazyl) dye. Tannins were determined using Folin Denis reagent according to the method described by Saxena et al. ${ }^{15}$. Ascorbic acid was determined by colorimetric method ${ }^{16}$ and expressed as $\mathrm{mg} / 100 \mathrm{~g}$. Water solubility index (WSI), water absorption index (WAI) and oil absorption index (OAI) were determined using the methods described by Beuchat ${ }^{17}$. Foam capacity and foam stability were measured using the method described by Narayana and Narasinga Rao ${ }^{18}$.

\section{Mineral analysis}

Minerals were determined by thermo-electron inductively coupled plasma atomic emission spectrometry (ICP-AES; model iCAP-630). One gram of dry sample was taken in a conical flask to which $10 \mathrm{ml}$ of diacid (nitric acid + perchloric acid $(3: 1))$ was added and left overnight. Then the mixture was digested until white fumes were observed $^{19}$.

\section{Statistical analysis}

The experiments were conducted in triplicate and results represented as mean \pm standard deviation (SD) of three replicate assays. Data were analysed using SPSS Statistics 24.0 (IBM, NY, USA) to test the variance and compared by Duncan's multiple range test. The means were considered to be statistically significant at $P<0.05$. Log values of all parameters were used to generate a heat map.

\section{Results and discussion}

\section{Malting loss}

The malting loss was non-significant $(P \leq 0.05)$ in the first $12 \mathrm{~h}$ of germination. However, significant $(P \leq 0.05)$ malting loss was observed on further germination. The variety used in the study, i.e. V L Mandua-315 had a malting loss of $35.39 \%$ after $96 \mathrm{~h}$ of germination, which was the highest among all the values reported earlier. Kumar $^{20}$ had reported a malting loss of $30 \%$ in a finger millet variety native to Himachal Pradesh. Nirmala et $a l{ }^{21}$ reported a malting loss of $32.5 \%$ in the Indaf- 15 variety of finger millet. During germination, the increased metabolic activities resulted in partial degradation of carbohydrates and thus loss of dry weight ${ }^{21}$. Another reason for the high malting loss in this variety might be the smaller seed size.

\section{Effect of germination on nutritional composition}

Soaking had a non-significant $(P \leq 0.05)$ effect on the sugar content of finger millet. However, germination time had a positive linear relationship with the sugar content. Reducing sugars increased from initial $0.86 \%$ to $10.54 \%$ and total sugars from $1.70 \%$ to $16.10 \%$ after $96 \mathrm{~h}$ of germination. Starch was negatively correlated with germination time and reduced from initial $62.83 \%$ to $41.19 \%$ after $96 \mathrm{~h}$ of germination. The increase in sugars and decrease in starch might be due to the breakdown of starch into sugars during germination. Seed germination is a complex phenomenon in which due to the activity of hydrolytic enzymes starch is broken down to sugars and other intermediates ${ }^{22}$. Evans et al. $^{23}$ had reported an increase in sugars on germination of barley. Similar results were documented by Nirmala et $a l^{21}$, who reported an increase in reducing sugars and total sugars from $1.44 \%$ to $8.36 \%$ and $1.5 \%$ to $16 \%$ respectively, after four days of germination. Malleshi and Desikachar ${ }^{24}$ reported $3.3 \%$ and $5.9 \%$ free sugars in finger millet germinated for $48 \mathrm{~h}$ and $96 \mathrm{~h}$ respectively. A decrease in starch content from $65 \%$ to $43 \%$ and $65.5 \%$ to $53.6 \%$ was reported after $96 \mathrm{~h}$ of germination ${ }^{21,24}$. The maximum change in sugars and starch content of finger millet was found after $48 \mathrm{~h}$ of germination (Table 1). This might be due to high amylase activity in between 48 and $72 \mathrm{~h}$ of germination $^{21}$. 
Table 1. Effect of germination time on physico-chemical parameters of finger millet

\begin{tabular}{|c|c|c|c|c|c|c|c|c|}
\hline $\begin{array}{l}\text { Parameters } \rightarrow \\
\text { Treatments } \downarrow\end{array}$ & $\begin{array}{c}\text { Malting loss } \\
(\%)\end{array}$ & $\begin{array}{c}\text { Reducing } \\
\text { sugars (\%) }\end{array}$ & $\begin{array}{c}\text { Total sugars } \\
(\%)\end{array}$ & Starch $(\%)$ & Protein $(\%)$ & Fat $(\%)$ & Ash (\%) & Crude fibre $(\%)$ \\
\hline Non-germinated & $0.00^{\mathrm{i}}$ & $0.86 \pm 0.06^{\mathrm{g}}$ & $1.70 \pm 0.10^{\mathrm{h}}$ & $62.83 \pm 0.65^{\mathrm{a}}$ & $6.04 \pm 0.14^{\mathrm{a}}$ & $0.57 \pm 0.02^{\mathrm{d}}$ & $2.27 \pm 0.12^{\mathrm{a}}$ & $3.74 \pm 0.16^{\mathrm{g}}$ \\
\hline Soaked & $1.03 \pm 0.21^{\mathrm{h}}$ & $0.77 \pm 0.02^{\mathrm{g}}$ & $1.77 \pm 0.10^{\mathrm{h}}$ & $61.52 \pm 1.46^{\mathrm{b}}$ & $5.86 \pm 0.14^{\mathrm{b}}$ & $0.56 \pm 0.03^{\mathrm{cd}}$ & $2.09 \pm 0.12^{\mathrm{b}}$ & $3.84 \pm 0.06^{\mathrm{fg}}$ \\
\hline $12 \mathrm{~h}$ & $1.10 \pm 0.10^{\mathrm{h}}$ & $1.32 \pm 0.05^{\mathrm{f}}$ & $2.18 \pm 0.12^{\mathrm{gh}}$ & $58.60 \pm 0.74^{\mathrm{c}}$ & $5.69 \pm 0.07^{\mathrm{bc}}$ & $0.50 \pm 0.02^{\mathrm{de}}$ & $2.07 \pm 0.06^{\mathrm{b}}$ & $3.87 \pm 0.08^{\mathrm{fg}}$ \\
\hline $24 \mathrm{~h}$ & $2.49 \pm 0.09^{\mathrm{g}}$ & $1.40 \pm 0.05^{\mathrm{f}}$ & $2.42 \pm 0.12^{\mathrm{g}}$ & $56.94 \pm 0.79^{d}$ & $5.65 \pm 0.07^{\mathrm{bc}}$ & $0.50 \pm 0.02^{\mathrm{de}}$ & $2.07 \pm 0.06^{\mathrm{b}}$ & $4.11 \pm 0.17^{\mathrm{de}}$ \\
\hline $36 \mathrm{~h}$ & $8.52 \pm 0.45^{\mathrm{f}}$ & $3.15 \pm 0.09^{\mathrm{e}}$ & $4.60 \pm 0.09^{f}$ & $53.84 \pm 0.40^{\mathrm{e}}$ & $5.63 \pm 0.12^{\mathrm{d}}$ & $0.46 \pm 0.03^{\mathrm{e}}$ & $1.93 \pm 0.03^{\mathrm{c}}$ & $4.31 \pm 0.10^{\mathrm{d}}$ \\
\hline $48 \mathrm{~h}$ & $14.37 \pm 0.51^{\mathrm{e}}$ & $3.31 \pm 0.04^{\mathrm{e}}$ & $5.53 \pm 0.10^{\mathrm{e}}$ & $51.87 \pm 0.45^{\mathrm{f}}$ & $5.51 \pm 0.09^{\mathrm{e}}$ & $0.41 \pm 0.02^{\mathrm{f}}$ & $1.77 \pm 0.05^{\mathrm{d}}$ & $4.38 \pm 0.28^{\mathrm{cd}}$ \\
\hline $60 \mathrm{~h}$ & $20.71 \pm 0.65^{d}$ & $5.48 \pm 0.20^{\mathrm{d}}$ & $8.45 \pm 0.38^{d}$ & $49.33 \pm 0.59^{\mathrm{g}}$ & $5.10 \pm 0.13^{\mathrm{f}}$ & $0.53 \pm 0.03^{\mathrm{d}}$ & $1.71 \pm 0.03^{\mathrm{de}}$ & $4.65 \pm 0.15^{\mathrm{bc}}$ \\
\hline $72 \mathrm{~h}$ & $26.03 \pm 0.40^{\mathrm{c}}$ & $7.39 \pm 0.17^{\mathrm{c}}$ & $11.95 \pm 0.64^{\mathrm{c}}$ & $47.77 \pm 0.26^{\mathrm{h}}$ & $4.40 \pm 0.10^{\mathrm{g}}$ & $0.63 \pm 0.03^{\mathrm{c}}$ & $1.63 \pm 0.05^{\mathrm{e}}$ & $4.76 \pm 0.23^{b}$ \\
\hline $84 \mathrm{~h}$ & $31.53 \pm 0.15^{\mathrm{b}}$ & $9.53 \pm 0.23^{b}$ & $14.43 \pm 0.58^{b}$ & $43.59 \pm 0.90^{\mathrm{i}}$ & $3.61 \pm 0.08^{\mathrm{h}}$ & $0.76 \pm 0.04^{b}$ & $1.50 \pm 0.08^{\mathrm{f}}$ & $4.94 \pm 0.31^{\mathrm{ab}}$ \\
\hline $96 \mathrm{~h}$ & $35.27 \pm 0.40^{\mathrm{a}}$ & $10.54 \pm 0.11^{\mathrm{a}}$ & $16.10 \pm 0.39^{\mathrm{a}}$ & $41.19 \pm 0.70^{\mathrm{j}}$ & $3.41 \pm 0.05^{\mathrm{i}}$ & $0.85 \pm 0.03^{\mathrm{a}}$ & $1.24 \pm 0.05^{\mathrm{g}}$ & $5.09 \pm 0.17^{\mathrm{a}}$ \\
\hline
\end{tabular}

Values are means $\pm \mathrm{SD}$. Values with the same superscript in a row are not significantly different at $P \leq 0.05$.

The protein content was reduced to $3.41 \%$ from initial $6.04 \%$ after $96 \mathrm{~h}$ of germination. These results are in agreement with other reported studies ${ }^{25,26}$. The decrease in protein content during germination might be due to the outpacing of protein synthesis by proteolysis, and hence, an increase in free amino acid content (lysine, tryptophan, methionine and cysteine) and migration of seed nitrogenous matter to the growing embryo ${ }^{27}$. However, some researchers reported increase in protein content on germination $^{28}$ and considered synthesis of enzyme proteins, imbibition and degradation of other constituents as the major reasons for increase in protein content.

The crude fat content decreased from $0.57 \%$ to $0.41 \%$ after $48 \mathrm{~h}$ of germination followed by a gradual increase and was found to be $0.85 \%$ in samples germinated for $96 \mathrm{~h}$. A decrease in crude fat content of finger millet was reported by Banusha and Vasantharuba ${ }^{25}$ after $36 \mathrm{~h}$ of germination. Lee et $a l^{29}$ reported a $10 \%$ decrease in crude fat of buckwheat after seven days of germination. Megat Rusydi et al. $^{27}$ found significant decrease in crude fat of $72 \mathrm{~h}$ germinated soybean, peanut and rice (white, black and brown). A decrease of 30-38\% fat content was reported for three cultivars of sorghum germinated for $72 \mathrm{~h}$ (ref. 30). The decrease in fat with increase in germination might be due to oxidation of fat to fatty acids and water, and use as a carbon source ${ }^{27,31}$. On the contrary, Obizoba and $\mathrm{Atii}^{32}$ reported $100 \%$ increase in fat content of sorghum germinated for $96 \mathrm{~h}$. Elkhier and Hamid $^{33}$ reported an increase of $78 \%$ and $42 \%$ of fat in two sorghum cultivars. The increase in fat content on prolonged germination might be due to the replacement of sugars as energy source, depletion of carbohydrates and hence increase in the percentage of fat present in the grains.

Germination above $24 \mathrm{~h}$ resulted in a significant increase in crude fibre. The crude fibre increased from initial $3.74 \%$ to $5.09 \%$ after $96 \mathrm{~h}$ of germination. A similar increase of crude fibre was reported by Malleshi and Klopfenstein $^{34}$ in $96 \mathrm{~h}$ germinated finger millet. The increase in crude fibre content might be due to rapid loss of starchy components. Parts of roots and shoots that remain adhered to millet grains after deculming can also increase the crude fibre content.

Germination had a negative effect on ash content, which reduced from initial $2.27 \%$ to $1.24 \%$ post $96 \mathrm{~h}$ of germination. The lower ash content of germinated grains might be due to the use of some of minerals in seeds sprouting metabolism ${ }^{35}$. The loss of the bran layer due to abrasion in the process of removal of roots and shoots of germinated grains might also be responsible for the loss of minerals ${ }^{36}$. Other studies have reported similar results $^{24,27,34}$.

\section{Effect of germination on bioactive compounds}

Table 2 depicts the effect of germination time on bioactive compounds such as total phenols, ascorbic acid, tannins and antioxidant activity. Polyphenols play an important role in maintaining body functions and health ${ }^{4}$. The major polyphenols in cereals are phenolic acids and tannins with a small amount of flavonoids ${ }^{3}$. In this study, it was found that the total phenol content in nongerminated finger millet grains was $1.50 \%$, which decreased to $0.49 \%$ after $24 \mathrm{~h}$ of germination. However, prolonged germination time increased the phenol content and it was found to be $1.13 \%$ after $96 \mathrm{~h}$ of germination. A similar trend was observed in tannins and after an initial decrease, a gradual increase in tannin content was found with increase in germination time (Table 2). Decrease in phenols and tannins on germination can be attributed to leaching of polyphenols in soaking water and increased enzymatic action during germination ${ }^{10}$. However, an increase in polyphenols on prolonged germination might be due to the increase in the total percentage of seed coat in later stages of germination because of the loss of carbohydrates. The phenols and tannins are generally concentrated in the seed coat (pericarp and aleurone layer) of the grains ${ }^{37}$. The ascorbic acid content of finger millet increased during germination from 9.76 to $17.40 \mathrm{mg} / 100 \mathrm{~g}$ after $96 \mathrm{~h}$ of germination. The increase in ascorbic acid might be due to vegetative growth which is 
Table 2. Effect of germination time on bioactive compounds of finger millet

\begin{tabular}{lcccc}
\hline $\begin{array}{l}\text { Parameters } \rightarrow \\
\text { Treatments } \downarrow\end{array}$ & $\begin{array}{c}\text { Total phenols } \\
(\% \text { as gallic acid equivalent })\end{array}$ & $\begin{array}{c}\text { Ascorbic acid } \\
(\mathrm{mg} / 100 \mathrm{~g})\end{array}$ & $\begin{array}{c}\text { Tannins } \\
(\mathrm{mg} / 100 \mathrm{~g} \text { as tannic acid) }\end{array}$ & $\begin{array}{c}\text { Antioxidant } \\
\text { activity }(\%)\end{array}$ \\
\hline Non-germinated & $1.50 \pm 0.05^{\mathrm{a}}$ & $9.76 \pm 0.24^{\mathrm{e}}$ & $173.7 \pm 11.5^{\mathrm{a}}$ & $72.22 \pm 1.93^{\mathrm{e}}$ \\
Soaked & $0.80 \pm 0.15^{\mathrm{d}}$ & $8.40 \pm 0.13^{\mathrm{f}}$ & $133.0 \pm 8.5^{\mathrm{b}}$ & $67.77 \pm 1.92^{\mathrm{f}}$ \\
$12 \mathrm{~h}$ & $0.67 \pm 0.005^{\mathrm{de}}$ & $7.48 \pm 0.12^{\mathrm{g}}$ & $121.1 \pm 2.8^{\mathrm{b}}$ & $57.77 \pm 1.92^{\mathrm{g}}$ \\
$24 \mathrm{~h}$ & $0.49 \pm 0.06^{\mathrm{g}}$ & $9.99 \pm 0.20^{\mathrm{e}}$ & $90.0 \pm 5.6^{\mathrm{cd}}$ & $74.44 \pm 1.92^{\mathrm{de}}$ \\
$36 \mathrm{~h}$ & $0.57 \pm 0.08^{\mathrm{ef}}$ & $11.67 \pm 0.22^{\mathrm{d}}$ & $66.3 \pm 5.1^{\mathrm{f}}$ & $77.77 \pm 1.92^{\mathrm{cd}}$ \\
$48 \mathrm{~h}$ & $0.65 \pm 0.05^{\mathrm{de}}$ & $12.01 \pm 0.45^{\mathrm{d}}$ & $64.3 \pm 9.7^{\mathrm{f}}$ & $78.88 \pm 1.92^{\mathrm{bc}}$ \\
$60 \mathrm{~h}$ & $0.83 \pm 0.10^{\mathrm{cd}}$ & $16.53 \pm 0.31^{\mathrm{c}}$ & $75.2 \pm 8.3^{\mathrm{ef}}$ & $82.22 \pm 1.93^{\mathrm{ab}}$ \\
$72 \mathrm{~h}$ & $1.00 \pm 0.03^{\mathrm{bc}}$ & $16.91 \pm 0.30^{\mathrm{bc}}$ & $78.5 \pm 5.93^{\mathrm{ef}}$ & $82.22 \pm 1.93^{\mathrm{ab}}$ \\
$84 \mathrm{~h}$ & $1.06 \pm 0.13^{\mathrm{b}}$ & $17.21 \pm 0.29^{\mathrm{b}}$ & $85.2 \pm 10.00^{\mathrm{cd}}$ & $83.33 \pm 3.34^{\mathrm{a}}$ \\
$96 \mathrm{~h}$ & $1.13 \pm 0.10^{\mathrm{b}}$ & $17.40 \pm 0.17^{\mathrm{a}}$ & $94.66 \pm 12.00^{\mathrm{c}}$ & $84.44 \pm 1.92^{\mathrm{a}}$ \\
\hline
\end{tabular}

Values are means \pm SD. Values with the same superscript in a row are not significantly different at $P \leq 0.05$.

Table 3. Effect of germination time on the functional properties of finger millet

\begin{tabular}{lccccc}
\hline $\begin{array}{l}\text { Parameters } \rightarrow \\
\text { Treatments } \downarrow\end{array}$ & $\begin{array}{c}\text { WSI } \\
(\%)\end{array}$ & $\begin{array}{c}\text { WAI } \\
(\mathrm{ml} / \mathrm{g})\end{array}$ & $\begin{array}{c}\text { OAI } \\
(\mathrm{ml} / \mathrm{g})\end{array}$ & $\begin{array}{c}\text { Foam capacity } \\
(\%)\end{array}$ & $\begin{array}{c}\text { Foam stability } \\
(\%)\end{array}$ \\
\hline Non-germinated & $3.64 \pm 0.04^{\mathrm{f}}$ & $1.33 \pm 0.03^{\text {cd }}$ & $2.22 \pm 0.02^{\mathrm{g}}$ & $12.33 \pm 0.58^{\mathrm{b}}$ & $51.00 \pm 1.00^{\mathrm{cd}}$ \\
Soaked & $3.36 \pm 0.04^{\mathrm{g}}$ & $1.27 \pm 0.05^{\mathrm{de}}$ & $2.12 \pm 0.03^{\mathrm{h}}$ & $11.67 \pm 0.58^{\mathrm{c}}$ & $49.33 \pm 1.15^{\mathrm{d}}$ \\
$12 \mathrm{~h}$ & $3.39 \pm 0.10^{\mathrm{g}}$ & $1.28 \pm 0.04^{\mathrm{de}}$ & $2.26 \pm 0.04^{\mathrm{f}}$ & $13.00 \pm 1.00^{\mathrm{b}}$ & $70.33 \pm 0.58^{\mathrm{a}}$ \\
$24 \mathrm{~h}$ & $3.65 \pm 0.06^{\mathrm{f}}$ & $1.30 \pm 0.02^{\mathrm{de}}$ & $2.36 \pm 0.02^{\text {cd }}$ & $15.33 \pm 0.78^{\mathrm{a}}$ & $72.00 \pm 1.00^{\mathrm{a}}$ \\
$36 \mathrm{~h}$ & $6.05 \pm 0.28^{\mathrm{b}}$ & $1.31 \pm 0.03^{\mathrm{c}}$ & $2.39 \pm 0.03^{\mathrm{c}}$ & $15.33 \pm 0.58^{\mathrm{a}}$ & $60.67 \pm 1.15^{\mathrm{b}}$ \\
$48 \mathrm{~h}$ & $6.43 \pm 0.06^{\mathrm{d}}$ & $1.33 \pm 0.03^{\mathrm{bcd}}$ & $2.45 \pm 0.04^{\mathrm{b}}$ & $11.67 \pm 0.58^{\mathrm{c}}$ & $50.67 \pm 1.15^{\text {cd }}$ \\
$60 \mathrm{~h}$ & $8.47 \pm 0.06^{\mathrm{c}}$ & $1.45 \pm 0.04^{\mathrm{a}}$ & $2.52 \pm 0.02^{\mathrm{a}}$ & $11.33 \pm 0.58^{\mathrm{c}}$ & $42.00 \pm 2.00^{\mathrm{e}}$ \\
$72 \mathrm{~h}$ & $8.56 \pm 0.04^{\mathrm{c}}$ & $1.39 \pm 0.03^{\mathrm{b}}$ & $2.35 \pm 0.01^{\mathrm{de}}$ & $9.67 \pm 0.58^{\mathrm{d}}$ & $40.67 \pm 1.15^{\mathrm{e}}$ \\
$84 \mathrm{~h}$ & $14.76 \pm 0.06^{\mathrm{b}}$ & $1.37 \pm 0.01^{\mathrm{bc}}$ & $2.37 \pm 0.02^{\text {cd }}$ & $9.00 \pm 1.00^{\mathrm{d}}$ & $51.33 \pm 1.15^{\text {cd }}$ \\
$96 \mathrm{~h}$ & $15.73 \pm 0.09^{\mathrm{a}}$ & $1.32 \pm 0.01^{\text {cde }}$ & $2.31 \pm 0.02^{\mathrm{e}}$ & $7.33 \pm 0.58^{\mathrm{e}}$ & $53.33 \pm 3.06^{\mathrm{c}}$ \\
\hline
\end{tabular}

WAI, Water absorption index; WSI, Water solubility index and OAI, Oil absorption index. Values are means $\pm \mathrm{SD}$. Values with the same superscript in a row are not significantly different at $P \leq 0.05$.

known to enhance ascorbic acid content. An increase in ascorbic acid has also been reported by Malleshi and Desikachar $^{25}$ during germination of finger millet. Antioxidant activity also get enhanced with germination time. This may be attributed to increase in ascorbic acid content during germination.

\section{Effect of germination on functional properties}

Functional properties of grains are of great significance in product development. These properties get changed during germination and hence their study is crucial for product development. WAI and OAI are important parameters in pasta and macaroni ${ }^{37}$. WSI is important for the development of cereal-based drinks. The changes in functional properties are mainly due to changes in composition and structure of carbohydrates and proteins ${ }^{38}$. Germination has also been reported to decrease the amylose content of $\operatorname{starch}^{39}$ and reduce the proteins of high molecular weight ${ }^{40}$. Table 3 presents the changes in functional properties of finger millet during $96 \mathrm{~h}$ of germination. WSI increased significantly with increase in germination time and was found to be $15.73 \%$ after $96 \mathrm{~h}$ of germination. The increase in WSI might be due to increase in sugar content (Table 1) and breakdown of starch into smaller granules. WAI and OAI increased up to $60 \mathrm{~h}$ of germination followed by a linear decrease. This increase in WAI and OAI can be attributed to the increase in damaged starch and surface area. Damaged starch is more hygroscopic than native starch and hence absorbs more water ${ }^{41}$. Similar results were reported by Adeniyi and Obatolu $^{42}$ in the germination of Amaranthus grains. The decrease in WAI and OAI after $60 \mathrm{~h}$ of germination might be due to the breakdown of starch to sugars and reduction in starch content.

Foam capacity and foam stability depend upon several factors like protein concentration, salts, sugars, lipids, temperature and $\mathrm{pH}^{43}$. Foam capacity increased up to $36 \mathrm{~h}$ of germination followed by a significant decrease. A similar trend was observed in foam stability and with increase in germination time the stability of foam also increased, which might be due to the increased concentration of sugars and salts. A decrease in protein content might be responsible for loss of foaming properties (Table 1).

\section{Effect of germination on mineral content}

The mineral content in non-germinated samples was within the range reported earlier ${ }^{4}$. All minerals, except 


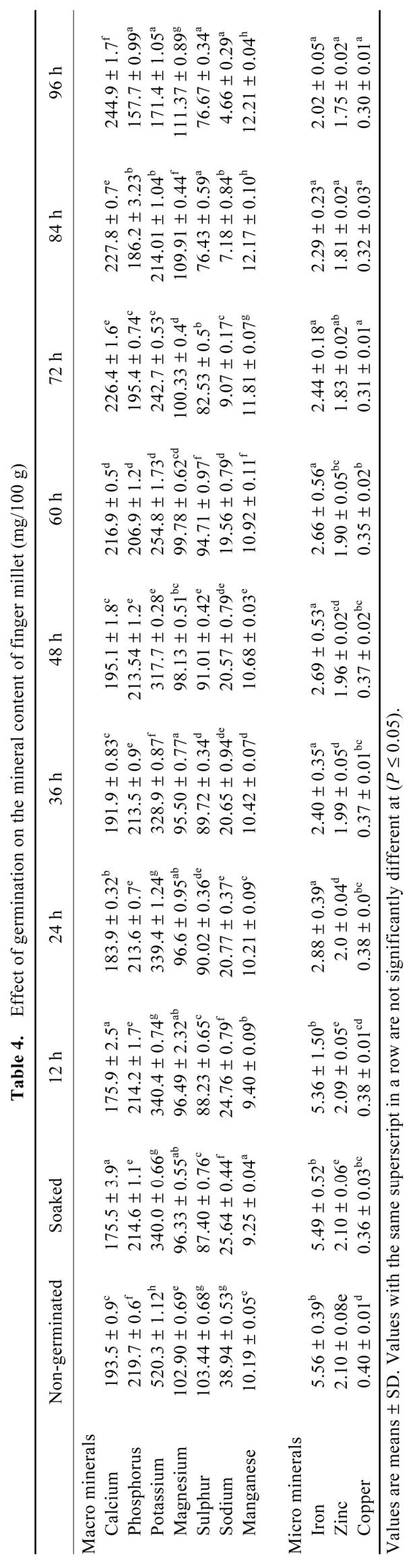




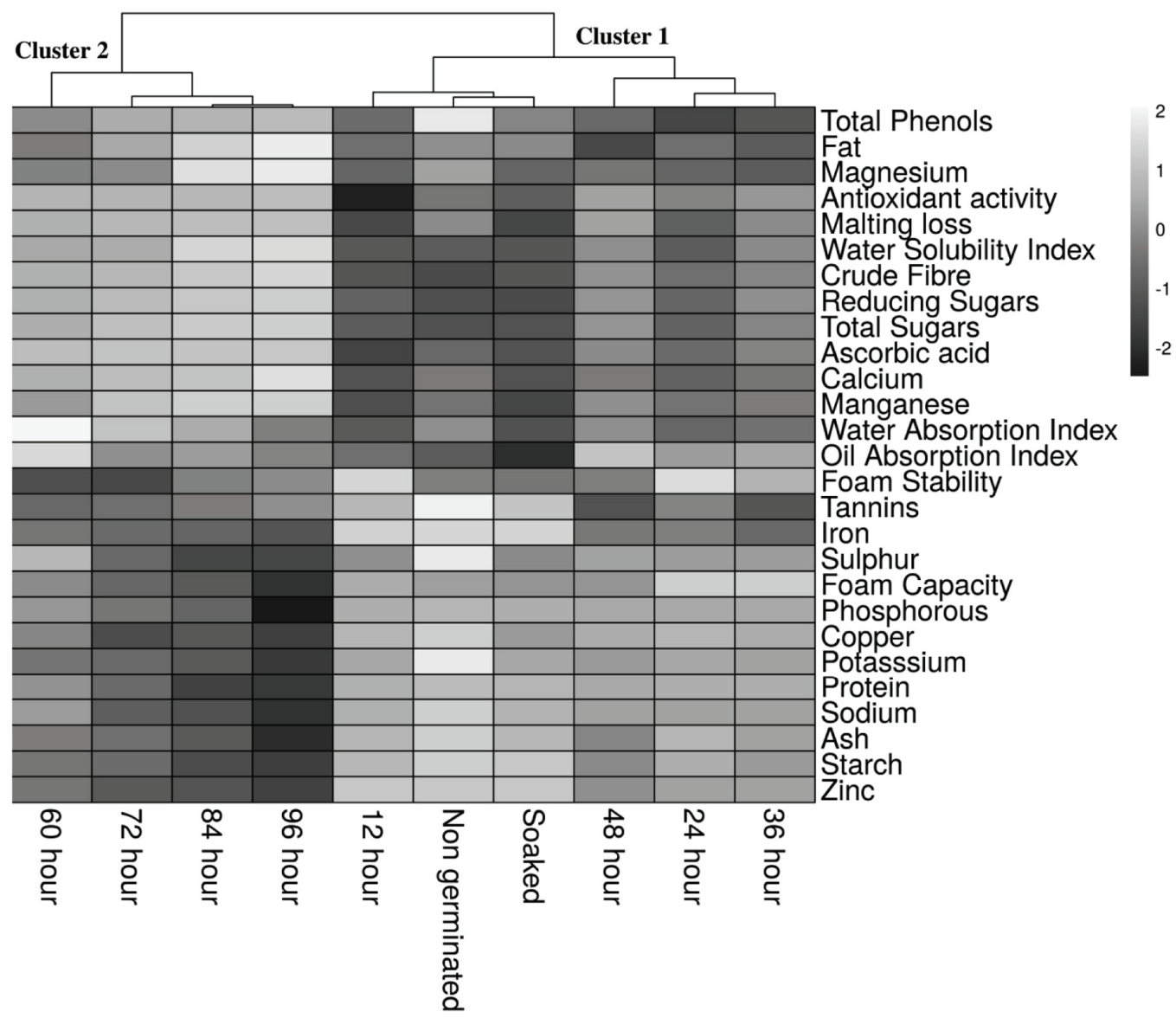

Figure 1. Clustered heat map depicting the effect of germination time on overall properties of finger millet.

zinc, showed significant loss upon soaking (Table 4). This might be due to the leaching of minerals in soaking water. The calcium content of non-germinated finger millet grains reduced after soaking followed by a linear increase with increase in germination time. These results are comparable with those of Suma and Urooj ${ }^{26}$, who reported an increase in calcium content of pearl millet on germination for $72 \mathrm{~h}$. The increase in calcium might be due to loss of organic dry matter from the grains during germination and hence increase in the percentage of calcium in the grains. Phosphorus showed a linear decrease with increase in germination time and a loss of $28 \%$ phosphorus was noticed after $96 \mathrm{~h}$ of germination. These results are in contradiction to Azeke et al. ${ }^{44}$, who reported $6 \%$ increase in phosphorus content of three days germinated sesame seeds and $19.7 \%$ increase in phosphorus content of ten days germinated millets. Plants require phosphorus for complex energy transmission and early root formation ${ }^{45}$, which might be the reason for the decrease in phosphorus content. A decreasing trend was found for potassium, sodium and sulphur. This decrease might be due to solubility and leaching of these minerals in soaking water. Magnesium and manganese decreased with soaking, but a linear increase in their contents was found with increase in the germination time. Luo et al. ${ }^{46}$ reported decrease in manganese content on $48 \mathrm{~h}$ germinated cereals and legumes.

Microminerals like iron, zinc and copper are considered essential elements in human nutrition. Germination had a negative effect on iron, zinc and copper and there was $63.7 \%, 16.7 \%$ and $25 \%$ reduction in these trace elements after $96 \mathrm{~h}$ of germination. These findings are in agreement with those Luo and $\mathrm{Xie}^{47}$, who reported a decrease of $38.2-38.9 \%$ iron and $24.5-29.2 \%$ of zinc on $72 \mathrm{~h}$ germination of faba beans. However, these results are in contrast with other studies ${ }^{26,46}$ which reported an increase in these trace minerals on germination.

\section{Clustered heat map}

A cluster heat map was generated using log values to show the effect of germination on the overall properties of finger millet (Figure 1). Grey scale was used for visualization of the heat map. The darker the intensity of the white colour, lesser is the content of the corresponding parameter/nutritional content, whereas darker the intensity of black colour, higher is the content. It is clear from the 


\section{RESEARCH ARTICLES}

grayscale variation that minerals, like zinc, sodium, potassium, copper, phosphorus and sulphur showed more or less similar trends across variation in germination times. Hierarchical tree cluster across germination times was divided into two groups. Cluster one comprised nongerminated, soaked, $12-48 \mathrm{~h}$ germinated finger millet grains. The second cluster consisted of grains germinated for $60-96 \mathrm{~h}$. It is evident from the heat map that the most noticeable changes took place between 12 and 24, 48 and 60,84 and $96 \mathrm{~h}$ of germination.

\section{Conclusion}

Germination time had a significant effect on the physicochemical characteristics, functional attributes as well as mineral content. With increase in germination time there was an increase in sugars and crude fibre, while starch, proteins, fat and mineral content decreased. The total phenols and tannins contents decreased with germination; however, on prolonged germination (above $48 \mathrm{~h}$ ) increase in total phenols and tannins was observed. Germination also increased ascorbic acid content, antioxidant activity and functional properties like WSI, WAI, OAI, foaming capacity and foam stability. Calcium content increased with germination while there was a decrease in other minerals, like phosphorus, potassium, magnesium, sulphur, sodium, manganese, iron, zinc and copper. On the basis of the studied parameters, a germination time above $48 \mathrm{~h}$ is recommended for the preparation of malted drinks that usually require higher levels of sugars and water solubility. A prolonged germination above $72 \mathrm{~h}$ resulted in high malting loss and increase in anti-nutrients. Hence, prolonged germination of finger millet grains should be avoided.

1. Saxena, R., Sai, V., Jin, W., Valérie, O. and Vijaya, R., Millets for food security in the context of climate change: a review. Sustainability, 2018, 10(7), 2228.

2. Saleh, A. S., Zhang, Q., Chen, J. and Shen, Q., Millet grains: nutritional quality, processing, and potential health benefits. Compr. Rev. Food Sci. Food Saf., 2013, 12(3), 281-295.

3. Kaur, P., Purewal, S. S., Sandhu, K. S., Kaur, M. and Salar, R. K., Millets: a cereal grain with potent antioxidants and health benefits. J. Food Meas. Character., 2019, 13(1), 793-806.

4. Kumar, A., Tomer, V., Kaur, A., Kumar, V. and Gupta, K. Millets: a solution to agrarian and nutritional challenges. Agric. Food Security, 2018, 7(1), 31.

5. ICAR-ACRIP, 2018; http://www.aicrpsm.res.in/Downloads/ Reports/ICAR-AICRP\%20reports-2017-18/1-Introduction.pdf (accessed on 3 June 2018).

6. Chandra, D., Chandra, S. and Sharma, A. K., Review of finger millet (Eleusine coracana (L.) Gaertn): a power house of health benefiting nutrients. Food Sci. Human Wellness, 2016, 5(3), 149155

7. Karuppasamy, P., Malathi, D., Banumathi, P., Varadharaju, N. and Seetharaman, K., Evaluation of quality characteristics of bread from kodo, little and foxtail millets. Int. J. Food Sci., 2012, 2(2), $35-39$.
8. Viswanath, V., Urooj, A. and Malleshi, N. G., Evaluation of antioxidant and antimicrobial properties of finger millet polyphenols (Eleusine coracana). Food Chem., 2009, 114(1), 340-346.

9. Panwar, P., Dubey, A. and Verma, A. K., Evaluation of nutraceutical and antinutritional properties in barnyard and finger millet varieties grown in Himalayan region. J. Food Sci. Technol., 2016, 53(6), 2779-2787.

10. Udeh, H. O., Duodu, K. G. and Jideani, A. I., Effect of malting period on physicochemical properties, minerals, and phytic acid of finger millet (Eleusine coracana) flour varieties. Food Sci. Nutr., 2018, 6(7), 1858-1869.

11. Association of Official Analytical Chemists, Official Methods of Analysis, the Association of Official Analytical Chemists (17th edn) (ed. Horwitz, W.), AOAC International, Maryland, USA, 2010.

12. AACC, Approved Methods of the AACC, American Association of Cereal Chemists, St. Paul, USA, 2000, 10th edn.

13. Singleton, V. L. and Rossi, J. A., Colorimetry of total phenolics with phosphomolybdic-phosphotungstic acid reagents. Am. J. Enol. Viticult., 1965, 16(3), 144-158.

14. Brand-Williams, W., Cuvelier, M. E. and Berset, C. L., Use of a free radical method to evaluate antioxidant activity. $L W T-F o o d$ Sci. Technol., 1995, 28(1), 25-30.

15. Saxena, V., Mishra, G., Saxena, A. and Vishwakarma, K. R., A comparative study on quantitative estimation of tannins in Terminalia chebula, Terminalia belerica, Terminalia arjuna and Saraca indica using spectrophotometer. Asian J. Pharm. Clin. Res., 2013, 6(3), 148-149.

16. Ranganna, S., Handbook of Analysis and Quality Control for Fruit and Vegetable Production, Tata McGraw-Hill Publishing Co, New Delhi, 1986, 2 edn.

17. Beuchat, L. R., Functional and electrophoretic characteristics of succinylated peanut flour protein. J. Agric. Food Chem., 1977, 25(2), 258-261.

18. Narayana, K. and Narasinga Rao, M. S., Functional properties of raw and heat processed winged bean (Psophocarpus tetragonolobus) flour. J. Food Sci., 1982, 47(5), 1534-1538.

19. Arora, C. L. and Bajwa, M. S., Comparative study of some methods of oxidation of plant materials for elemental analysis. Curr. Sci., 1994, 66(4), 314-317.

20. Kumar, A., Refinement of the technology of the traditional 'sur' production in Himachal Pradesh. M Sc thesis, Dr. Y. S. Parmar University of Horticulture and Forestry, Solan, 2013.

21. Nirmala, M., Rao, M. S. and Muralikrishna, G., Carbohydrates and their degrading enzymes from native and malted finger millet (ragi, Eleusine coracana, Indaf-15). Food Chem., 2000, 69(2), 175-180.

22. Ferreira, C. D., Piedade, M. T., Tiné, M. A., Rossatto, D. R., Parolin, P. and Buckeridge, M. S., The role of carbohydrates in seed germination and seedling establishment of Himatanthus sucuuba, an Amazonian tree with populations adapted to flooded and non-flooded conditions. Ann. Bot., 2009, 104(6), 1111-1119.

23. Evans, E., van Wegen, B., Ma, Y. and Eglinton, J., The impact of the thermostability of $\alpha$-amylase, $\beta$-amylase, and limit dextrinase on potential wort fermentability. J. Am. Soc. Brew. Chem., 2003, 61(4), 210-218.

24. Malleshi, N. G. and Desikachar, H. S., Influence of malting conditions on quality of finger millet malt. J. Inst. Brew., 1986, 92(1), 81-83.

25. Banusha, S. and Vasantharuba, S., Effect of malting on nutritional contents of finger millet and mung bean. Am.-Eurasian J. Agric. Environ. Sci., 2013, 13(12), 1642-1646.

26. Suma, P. F. and Urooj, A., Influence of germination on bioaccessible iron and calcium in pearl millet (Pennisetum typhoideum). J. Food Sci. Technol., 2014, 51(5), 976-981.

27. Megat Rusydi, M. R., Noraliza, C. W., Azrina, A. and Zulkhairi, A., Nutritional changes in germinated legumes and rice varieties. Int. Food Res. J., 2011, 18(2), 688-696. 
28. Handa, V., Kumar, V., Panghal, A., Suri, S. and Kaur, J., Effect of soaking and germination on physicochemical and functional attributes of horsegram flour. J. Food Sci. Technol., 2017, 54(13), 4229-4239.

29. Lee, M. H, Lee, J. S. and Lee, T. H., Germination of buckwheat grain: effects on minerals, rutin, tannins and colour. In Advances in Buckwheat Research: Proceedings of the 9th International Symposium on Buckwheat. Research Institute of Crop Production, Prague, Czech Republic, 2004, pp. 50-54.

30. Omary, M. B., Fong, C., Rothschild, J. and Finney, P., Effects of germination on the nutritional profile of gluten-free cereals and pseudocereals: a review. Cereal Chem., 2012, 89(1), 1-4.

31. Hahm, T. S., Park, S. J. and Lo, Y. M., Effects of germination on chemical composition and functional properties of sesame (Sesamum indicum L.) seeds. Bioresour. Technol., 2009, 100(4), 16431647.

32. Obizoba, I. C. and Atii, J. V., Effect of soaking, sprouting, fermentation and cooking on nutrient composition and some antinutritional factors of sorghum (Guinesia) seeds. Plant Foods Hum Nutr., 1991, 41(3), 203-212.

33. Elkhier, M. K. and Hamid, A. O., Effect of malting on the chemical constituents, antinutrition factors and ash composition of two sorghum cultivars (feterita and tabat) grown in Sudan. Res. J. Agric. Biol. Sci., 2008, 4(5), 500-504.

34. Malleshi, N. G. and Klopfenstein, C. F., Nutrient composition, amino acid and vitamin contents of malted sorghum, pearl millet, finger millet and their rootlets. Int. J. Food Sci. Nutr., 1998, 49(6), 415-422.

35. Enujiugha, V. N., Badejo, A. A., Iyiola, S. O. and Oluwamukomi, M. O., Effect of germination on the nutritional and functional properties of African oil bean (Pentaclethra macrophylla Benth) seed flour. J. Food Agric. Environ., 2003, 1, 72-75.

36. Hama, F., Icard-Vernière, C., Guyot, J. P., Picq, C., Diawara, B. and Mouquet-Rivier, C., Changes in micro- and macronutrient composition of pearl millet and white sorghum during in field versus laboratory decortication. J. Cereal Sci., 2011, 54(3), 425-433.

37. Kaur, G., Sharma, S., Nagi, H. P. and Dar, B. N., Functional properties of pasta enriched with variable cereal brans. J. Food Sci. Technol., 2012, 49(4), 467-474.

38. Tao, H., Wang, P., Ali, B., Wu, F, Jin, Z. and Xu, X., Structural and functional properties of wheat starch affected by multiple freezing/thawing cycles. Starch-Stärke, 2015, 67(7-8), 683-691.
39. Li, C., Oh, S. G., Lee, D. H., Baik, H. W. and Chung, H. J., Effect of germination on the structures and physicochemical properties of starches from brown rice, oat, sorghum, and millet. Int. J. Biol. Macromol., 2017, 105, 931-939.

40. Rumiyati, R., James, A. P. and Jayasena, V., Effect of germination on the nutritional and protein profile of Australian sweet lupin (Lupinus angustifolius L.). Food Nutr. Sci., 2012, 3(5), 621-626.

41. Horstmann, S. W., Lynch, K. M. and Arendt, E. K., Starch characteristics linked to gluten-free products. Foods, 2017, 6(4), 29.

42. Adeniyi, P. O. and Obatolu, V. A., Effect of germination temperature on the functional properties of grain Amaranthus. Am. J. Food Sci. Technol., 2014, 2(2), 76-79.

43. Kinsella, J. E., Functional properties of proteins: possible relationships between structure and function in foams. Food Chem., 1981, 7(4), 273-288.

44. Azeke, M. A., Egielewa, S. J., Eigbogbo, M. U. and Ihimire, I. G., Effect of germination on the phytase activity, phytate and total phosphorus contents of rice (Oryza sativa), maize (Zea mays), millet (Panicum miliaceum), sorghum (Sorghum bicolor) and wheat (Triticum aestivum). J. Food Sci. Technol., 2011, 48(6), 724-729.

45. Mullins, G., Phosphorus, agriculture and the environment, 2009; https://pubs.ext.vt.edu/content/dam/pubs_ext_vt_edu/424/424029/424-029_pdf.pdf (accessed on 15 June 2019).

46. Luo, Y. W., Xie, W. H., Jin, X. X., Wang, Q. and He, Y. J., Effects of germination on iron, zinc, calcium, manganese, and copper availability from cereals and legumes. CyTA-J. Food, 2014, 12(1), 22-26.

47. Luo, Y. and Xie, W., Effect of soaking and sprouting on iron and zinc availability in green and white faba bean (Vicia faba L.). J. Food Sci. Technol., 2014, 51(12), 3970-3976.

ACKNOWLEDGEMENT. We thank the Asia-Pacific Association of Agricultural Research Institutions, Bangkok, Thailand for providing research aid under CRP DC Scholarship Programme.

Received 10 January 2020; accepted 5 November 2020

doi: $10.18520 / \mathrm{cs} / \mathrm{v} 120 / \mathrm{i} 2 / 406-413$ 